\title{
A Brief History of Self-Reference Notion Implementation in Byzantium
}

Did the Byzantine Theologians and Scholars Formulate Russell's Paradox?

\author{
Oksana Yu. Goncharko \\ National Research University Higher School of Economics, St Petersburg, Russia \\ goncharko_oksana@mail.ru \\ Yuriy M. Romanenko \\ Saint-Petersburg State University, Russia \\ in_romanenko@rambler.ru
}

\begin{abstract}
The article presents an overview of implementation of self-referential notions in the logical and theological texts of Byzantine scholars up to the 12th century. The commentaries on Porphyry's and Aristotle's theory of definition by John of Damascus, John Italus, and Theodore Prodromos are discussed. It is argued that the Byzantine scholars performed different original implementations of basic logical notions and discovered their self-referential property. The attention is paid to the five predicabilia notions of Porphyry and Aristotelian categories applications in logical, philosophical, and theological Byzantine texts. The authors conclude that the Byzantine solutions resemble some of the modern logical ideas of 20 th century.
\end{abstract}

\section{Keywords}

Byzantine philosophy - history of logic - Russell's paradox - John of Damascus - John Italus - Theodore Prodromos

* The present study is a part of a larger project № 16-18-10202, "History of the Logical and Philosophical Ideas in Byzantine Philosophy and Theology," implemented with a financial support of the Russian Science Foundation. 


\section{Introduction}

Self-reference is a linguistic phenomenon of applying some expression to itself in natural (may appear in frames of art and literature) and formal (mathematical, logical, programming) languages. Self-reference has various applications in science and culture: ${ }^{1}$ non-well-founded set theory in logic and non-standard analysis, process algebra, linguistics and natural language semantics; ${ }^{2}$ recursion and reflection in computer science as a strategy for meta-programming; self-similarity in mathematics; meta-reference as art-making technique in fiction, theater, cinema, radio, television and even music (frame story in fiction, induction in theater, meta-joke in humor, ${ }^{3}$ hypostasis or meta-fiction and meta-discussion techniques in literature).

Self-reference as a phenomenon causing paradoxes is known even from the ancient times: Epimenides' liar paradox about all Cretans being liars; its Eubulides' formulation about a man saying that he is lying ( $\psi \varepsilon v \delta \delta$ ó - though not logically equivalent to Epimenides' variant); Socratic paradox

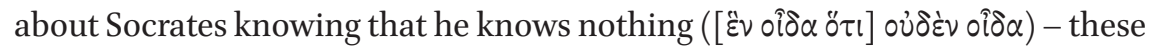
all are the variations of the same self-referential expressions. The Ancient and Western Medieval formulas of liar paradox are widely investigated ${ }^{4}$ in scientific modern literature (in the Middle Ages the liar paradox and paradoxes related to self-reference phenomenon were studied by western scholasts as

1 J. Roberts, The Logic of Reflection. German Philosophy in the Twentieth Century, New Haven London, 1992, p. 43.

2 P. Hughes, G. Brecht, Vicious Circles and Infinity - A Panoply of Paradoxes, Garden City - New York, 1975, pp. 1-8.

3 O. Yu. Goncharko, "Temporal Aspect Analysis of Ancient and Byzantine jokes," St. Petersburg State Polytechnical University Journal, St. Petersburg, 2016, № 3, pp. 16o-165.

4 J. Barwise, J. Etchemendy, The Liar: An Essay on Truth and Circularity, New York, 1989; C. J. Martin, "Obligations and Liars," in: Sophisms in Medieval Logic and Grammar, ed. S. Read, Dordrecht, 1993, pp. 357-381; C. D. Novaes, "Lessons on sentential meaning from medieval solutions to the liar paradox," Philosophical Quarterly, 59 (2009), pp. 682-704. Y. Iwakuma, S. Ebbesen, "Logico-Theological Schools from the Second Half of the Twelfth Century: A List of Sources," Vivarium, 30 (1992), pp. 173-210. Е. Н. Лисанюк, “Софистика - это не аргументация" [Е. N. Lisanyuk, "Sophistic vs Argumentation: the Ways of Demarcation”], Scholae 8, No 2 (2014), pp. 136-151. S. Read, "The Liar Paradox from John Buridan back to Thomas Bradwardine," Vivarium, 40 (2002), pp. 189-218. S. Read, "Plural Signification and the Liar Paradox," Philosophical Studies, 145 (2009), pp. 363-375. P. V. Spade, "The Origins of the Mediaeval Insolubilia-Literature," Franciscan Studies, 33 (1973), pp. 292-309. P. V. Spade, "The Mediaeval Liar: A Catalogue of the Insolubilia-Literature," Subsidia Mediaevalia, vol. 5, Toronto, 1975 . 
insolubles (insolubilia)): ${ }^{5}$ St. Jerome (4-5th cent.) made the comments on the phrase "Every man is a liar!" from Psalms (116:11) as on the liar paradox, ${ }^{6}$ Adam of Balsham studied paradoxical statements (approx. 1132), ${ }^{7}$ Alexander Neckham proposed solution for such paradoxes (12th cent.), the works of Thomas Bradwardine were also dedicated to similar matters, ${ }^{8}$ Roger Swyneshed ${ }^{9}$ and William Heytesbury ${ }^{10}$ observed these paradoxes in their particular way (14th cent.), Jean Buridan proposed his famous solutions to alethic paradoxes in his

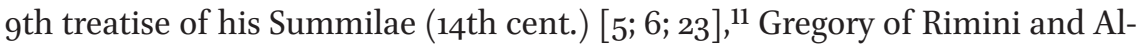

$5 \quad$ Peter of Ailly, "Concepts and Insolubles: An Annotated Translation," in: Synthese Historical Library, trans. P. V. Spade, vol. 19, Dordrecht, 1980; F. Pironet, "William Heytesbury and the treatment of Insolubilia in 14th-century England," in: Unity, Truth and the Liar: The Modern Relevance of Medieval Solutions to the Liar Paradox, ed. S. Rahman, T. Tulenheimo, E. Genot, Berlin, 2008, pp. 251-327; F. Pironet, "John Buridan on the Liar Paradox: Study of an Opinion and Chronology of the Texts," in: Argumentationstheorie: Scholastische Forschungenzuden logischen undsemantischen Regeln korrekten Folgerns, hg. K. Jacobi, Leiden - New York - Köln, 1993, pp. 293-300; P. V. Spade, "Ockham on Self-Reference," Notre Dame Journal of Formal Logic, 15 (1974), pp. 298-300; P. V. Spade, "William Heytesbury's Position on 'Insolubles': One Possible Source," Vivarium, 14 (1976), pp. 114-120; P. V. Spade, "John Buridan on the Liar: A Study and Reconstruction," Notre Dame Journal of Formal Logic, 19 (1978), pp. 579-59o; P. V. Spade, "Insolubilia and Bradwardine's Theory of Signification," Medioevo: Revista di storia della filosofia medievale, 7 (1981), pp. 115-134.

6 St. Jerome, Homily on Psalm 115 (116B), in: The Homilies of Saint Jerome, Vol. I, 1-59 On the Psalms, tr. Sr. M. L. Ewald, (The Fathers of the Church, 48), Washington, D.C., 1964, p. 294.

$7 \quad$ Twelfth Century Logic: Texts and Studies, Vol. I, Adam balsamiensis parvipontani. Ars disserendi (Dialectica Alexandri), ed. L. Minio-Paluello, Rome, 1956.

8 Thomas Bradwardine, Insolubilia, ed. and tr. S. Read (Dallas Medieval Texts and Translations), Leuven, 2010.

9 Roger Swyneshed, "Insolubilia," in: P. V. Spade, "Roger Swyneshed's Insolubilia: Edition and Comments," Archives d'histoire doctrinale et littéraire du moyen age, 46 (1979), pp. 177-220.

F. Pironet, "William Heytesbury and the treatment of Insolubilia in 14th-century England," in: Unity, Truth and the Liar: The Modern Relevance of Medieval Solutions to the Liar Paradox, ed. S. Rahman, T. Tulenheimo, E. Genot, Berlin, 2008, pp. 251-327. William Heytesbury, "On Insoluble Sentences: Chapter One of His Rules for Solving Sophisms," in: Mediaeval Sources in Translation, tr. P. V. Spade, vol. 21, Toronto, 1979.

John Buridan, "Sophismata," in: Grammatica Speculativa, ed. T. K. Scott, vol. 1, Stutgart Bad Cannstatt, 1977; John Buridan, "Summulae: De Practica Sophismatum," in: Critical edition of the Latin text, ed. F. Pironet, Turnhout, 2004; G. E. Hughes, "John Buridan on SelfReference," in: Chapter Eight of Buridan's "Sophismata," translated with an Introduction and a philosophical Commentary, ed. and tr. G. E. Hughes Cambridge, 1982. 
bert of Saxony also paid their tribute to the discussion about paradoxes (14th cent.), ${ }^{12}$ etc.)

The Eastern Medieval history of comments on liar paradox is also well investigated in literature: the Indian grammarian-philosopher Bhartrhari (5th cent.), ${ }^{13}$ a Sanskrit author, formulated a liar paradox (and its temporal contextualization solution) in the context of unsignifiability as follows: everything I am saying is false (is an unnameable thing considered named by calling it unnameable?). In Islamic philosophy there was the vast independent discussion (apart from other traditions) on liar paradox (9th-13th cent.) opened by Nasir al-Din al-Tusi (13th cent.) and defining it in self-referential terms. ${ }^{14}$ The only one part of the Eastern Medieval thought on paradoxes involving self-reference and their implementation in logic and theology which is not yet investigated is a Byzantine one..$^{15}$ This short note on the history of self-reference notion implementation in Byzantium is one of the first steps to fill this gap. Here we offer some arguments proving why it seems to us that the Byzantine scholars and theologians anticipated the Russell's Paradox.

\section{On Logical Paradoxes in General}

To begin with we should mention the basic ingredients of logical paradoxes in general, then we'll show that Byzantine scholars and theologians used them even all and implemented them to their thoughts and commentaries not only on Holy Texts, but also on Aristotle's and Porphyry's logical works.

The basic elements of logical paradoxes are usually as follows:

1. Self-reference.

2. Infinite regress.

12 Albert of Saxony, "Insolubles," in: The Cambridge Translations of Medieval Philosophical Texts, vol. I: Logic and the Philosophy of Language, tr. N. Kretzmann, E. Stump, Cambridge, 1988.

13 J. E. M. Houben, "Bhartrhari's solution to the Liar and some other paradoxes," Journal of Indian Philosophy, 23 (1995), pp. 381-401; J. E. M. Houben, "Paradoxe et perspectivisme dans la philosophie de langage de Bhartrhari: langage, pensée et réalité," Bulletin d'Études Indiennes, 19 (2001), pp. 173-199; J. E. M. Houben, Bhartrhari's Perspectivism, in: Beyond Orientalism, ed. E. Franko, K. Preisendanz, Amsterdam - Atlanta, 1997.

14 A. Alwishah, D. Sanson, "The Early Arabic Liar: the Liar Paradox in the Islamic World from the Mid-Ninth to the Mid-Thirteenth Centuries CE," Vivarium, 47 (2009), pp. 97-127.

15 S. Gerogiorgskis, "The Byzantine Liar," History and Philosophy of Logic, 30 (2009), pp. 313330. 
3. Circular definitions.

4. Confusion between different levels of abstraction.

5. Question as an initiating paradox form (the role of questioning in paradox is not usually mentioned, but the huge amount of different paradoxes variations were formulated exactly as questions).

The paradox laws outlined by P. Hughes are the following: ${ }^{16}$

1. Self-referential notions or statements.

2. Contradiction.

3. Vicious circularity or the corruption of the vicious circle principle.

One of the most famous logical paradoxes is the Russell's paradox which arises by considering the following notion - the set of all sets that are not members of themselves. ${ }^{17}$ Such a notion of set that appears to belong to itself if and only if it does not belong to itself. The paradox arises because of the self-referential property of such a notion and self-descriptive feature of the word "set" (the set of all sets)..$^{18}$ Negation is the second ingredient of the paradox (the set of all sets that are not members of themselves) that causes a contradiction (for such a set to be a member of itself if and only if it is not a member of itself). The Russell's paradox is a set-theoretical paradox because it reveals the paradoxical nature of the set theory built by Georg Cantor as mathematics foundation theory. ${ }^{19}$ In logic, mathematics and computer science, a type theory built by Bertrand Russell is considered to be the one of the possible alternative theories serving as a foundation for mathematics. ${ }^{20}$ This theory solves the Russell's par-

16 P. Hughes, G. Brecht, Vicious Circles and Infinity-A Panoply of Paradoxes, Garden City New York, Doubleday, 1975, pp. 1-8.

17 A. Cantini, "On a Russellian Paradox about Propositions and Truth," in: One Hundred Years of Russell's Paradox, ed. Godehard Link, Berlin - New York, 2004, pp. 259-284

18 A. Cantini, "Paradoxes, Self-Reference and Truth in the 2oth Century," in: Handbook of the History of Logic, Vol. 5, Logic From Russell to Church, ed. D. M. Gabbay, J. Woods, Amsterdam, 2009, pp. 875-1013.

19 A. Garciadiego, Bertrand Russell and the Origins of the Set-theoretic "Paradoxes", Boston, 1992; I. Grattan-Guinness, "How Bertrand Russell Discovered His Paradox," Historia Mathematica, 5 (1978), pp. 127-137

20 A. Church, Russellian Simple Type Theory, Proceedings and Addresses of the American Philosophical Association, 47 (1974), pp. 21-33; A. Church, "Set Theory with a Universal Set," in: Proceedings of the Tarski Symposium (1974), pp. 297-308, repr. in: International Logic Review, 15, pp. 11-23. A. Church, "A Comparison of Russell's Resolution of the Semantical Antinomies with that of Tarski," Journal of Symbolic Logic, 41 (1978), pp. 747-760. 
adox by restricting the operations usage: every "term" has a "type" and not all the operations are allowed to be applied to terms of any type. ${ }^{21}$

\subsection{On the History of Self-Reference Notion in Byzantium}

The theme of self-reference in Byzantium is a topic to be investigated. Now we'd like to tell about one possible line of its development: having found in Theodoros Prodromos' dialogue $\Xi \varepsilon v \varepsilon ́ \delta \eta \mu \varsigma^{22}$ self-reference notion as a method to set out aporias, sophismata and contradictions, we looked to a bigger picture of his possible sources - John Italus (a possible prototype of this dialogue's protagonist Theocles) and John of Damascus (as a text widely commented by Italus). Of course, this line of discussion on the self-reference notion development in Byzantium is not the only one to be reconstructed, discussed and investigated.

At first we should provide a brief sketch of the main stages of the definition theory development in Ancient Greek and Byzantine traditions to show how the idea of self-referential definitions occurred and developed till John of Damascus (8th cent.) and the time of Theodoros Prodromos (12th cent.). Generally speaking, the definition theory in Greek Aristotelian commentary tradition developed through three following stages.

\subsection{Late Antiquity Period}

Porphyry (3th cent.) created the definition theory, ${ }^{23}$ based on predicabilia no-

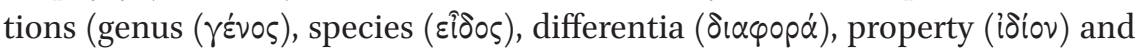
accident ( $\sigma \nu \mu \beta \varepsilon \beta \eta x$ ó $\left.^{\prime} \circ\right)$ )), that influenced a series of commentaries on Isagoge (Introduction) and Categories of Aristotle edited in Commentaria in Aristotelem Grecae. Commentary In Porphyrii Isagogen Sive V Voces (On Porphyry's Introduction or Five Voices) though having later interpolations is nevertheless attributed to Ammonius Hermiae (5th-6th cent.) and contains critics and modification of aristotlian theory of categories in terms of platonic ideas (some kind of synthesis of Plato and Aristotle). ${ }^{24}$ Being neoplatonic, such philosophers as

21 For more details see B. P. Andrews, An Introduction to Mathematical Logic and Type Theory: To Truth Through Proof, Kluwer Academic Publishers, 2002; B. Jacobs, Categorical Logic and Type Theory. Studies in Logic and the Foundations of Mathematics 141, North Holland, 1999; J. E. Collins, A History of the Theory of Types: Developments After the Second Edition of "Principia Mathematica", Lambert Academic Publishing, 2012. Theodore Prodromus, Xenedemus, sive Voces, in: Anecdota Graeca e codd. manuscriptis bibliothecarum Oxoniensium, ed. J. A. Cramer, Vol. 3 (Oxonii, 1836), pp. 204-215. Commentaria in Aristotelem Graeca, edita consilio et auctoritate academiae litterarum Regiae Borussicae, Vol. I-XXIII, 1882-1909, Vol. 4.1 (1887).

24 Commentaria in Aristotelem Graeca, Vol. 4.3, 1891. 
Ammonius and others (Elias and David (6th cent.)) commented on Porphyry in Porphyrii Isagogen et Aristotelis Categorias Commentaria (Commentaries on the Introduction of Porphyry and Categories of Aristotle $)^{25}$ and Porphyrii Isagogen commentarium (Commentary on Porphyry's Introduction), ${ }^{26}$ that also might be falsely ascribed to Elias and David. According to an argument of M. Richard, ${ }^{27}$ the organization of educational process in Alexandria proposed producing the lecture notes of Ammonius on Plato and Aristotle made by the

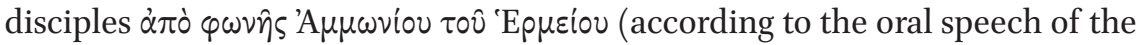
lecturer). For example, it may be such a case of In Aristotelis Categorias Commentarius (Commentary on Porphyry's Introduction) ascribed to Ammonius, ${ }^{28}$

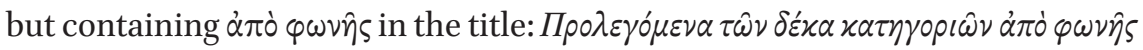

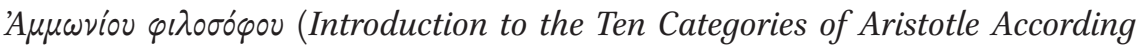
to the Oral Speech of Ammonius the Philosopher). ${ }^{29}$ The situation concerning commentaria by Elias and David is similar. Being disciples of Olympiodorus they constituted original tradition that later influenced the byzantine the-

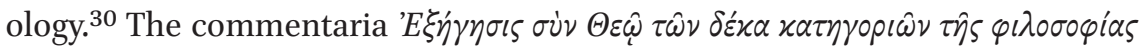

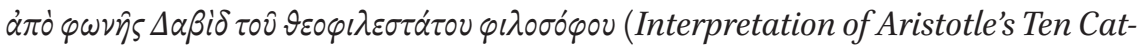
egories of Philosophy Made by Divine Inspiration According to the Oral Speech of David the Philosopher) made by Elias, are attributed to David in manu-

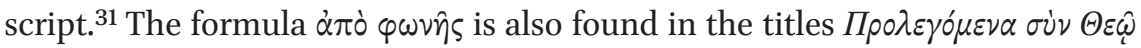

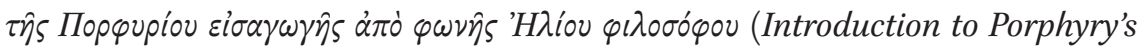
Introduction Made by Divine Inspiration According to the Oral Speech of Elias

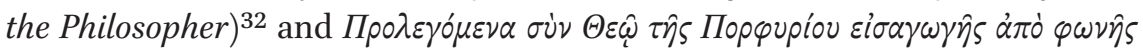

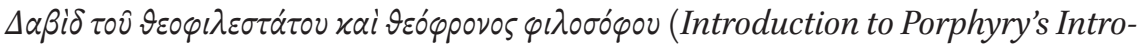
duction Made by Divine Inspiration According to the Oral Speech of David the Philosopher). ${ }^{33}$ Almost all of these authors also created platonic commentaries on Aristotle's and Porphyry's definition theories. Being platonic followers they tried to adapt Aristotle to Plato using Porphyry's instruments of argumentation that caused the reflection on the foundations of his definition theory but yet without applying the predicabilia notions to their own definitions (i.e. without investigating the self-referential nature of predicabilia terms). Nevertheless

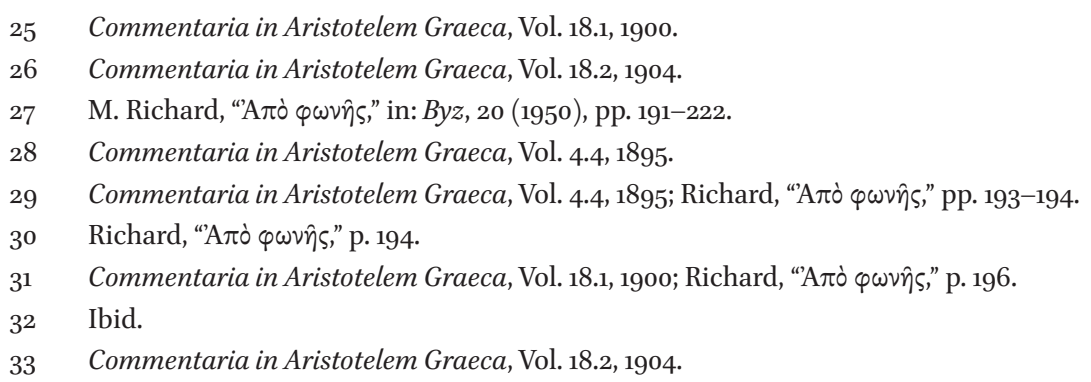


even without contributing directly to the development of the discussion on self-reference they formulated the tools, the apparatus and the approach to the commenting on Porphyry's and Aristotle's definition theory that influenced some later authors such as John of Damascus (8th cent.), John Italus (11th cent.) and Theodoros Prodromos (12th cent.).

\subsection{Middle Byzantine Period (8th-11th Cent.)}

John of Damascus (strictly speaking Byzantine commentator on Porphyry's Isagoge) in his Philosophical Chapters (

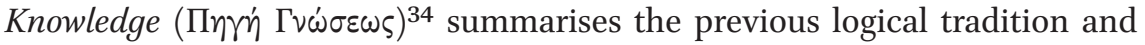
prepares it to be applied to solve some theological, philosophical and logical problems. That's why speaking about the ideas of Damascene we should imply not only his personal ideas but we should also consider his thoughts as the synopsis and tradition systematization.

He also shows that philosophical skepticism is a self-refuting phenomenon stating that it is impossible to know about the impossibility of knowledge (the analogue of liar paradox) as far as it is impossible to perceive the absence of perception: "There are, however, some people who have endeavored to do away entirely with philosophy by asserting that it does not exist and that neither does any knowledge or perception exist. We shall answer them by asking: How is it that you say that there is neither philosophy, nor knowledge, nor perception? Is it by your knowing and perceiving it, or is it by your not knowing and

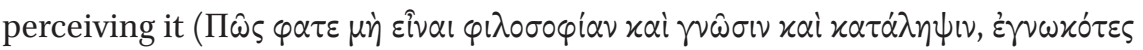

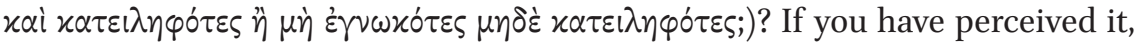
well, that is knowledge and perception. But if it is by your not knowing it, then no one will believe you, as long as you are discussing something of which you have no knowledge." ${ }^{35} \mathrm{He}$ disproved by such a contradiction the idea of scepticism because the falsehood of it is a consequence of its being true. It is necessary to note that this refutation is not his personal invention. He takes it from Greek philosophical tradition and puts it in the beginning of his work on knowledge.

In Chapter 5 of Philosophical Chapters which is dedicated to the term "term"

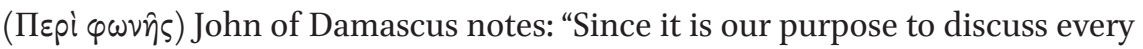

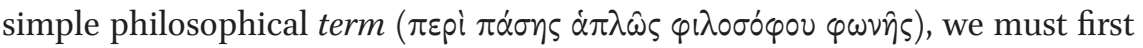

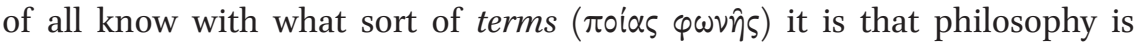

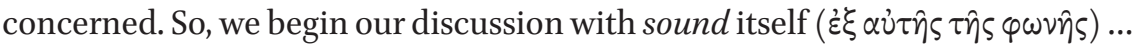

PG 94; Saint John of Damascus, Writings, tr. F. H. Chase (The Fathers of the Church. A New Translation, 37), Washington, 1958.

Saint John of Damascus, Writings, tr. Chase, pp. 12-13; PG 94, chap. 3. 
philosophy is concerned with that sound ( $\left.\varphi \omega v \eta^{\prime}\right)$ which has meaning, is articulate, and is universal, or, in other words, common and predicated of several things." ${ }^{36}$ In the Greek text John of Damascus uses three times the word $\varphi \omega v \eta$ and shows that the term $\varphi \omega \nu \eta$ is also $\varphi \omega v \eta$ itself, i.e. it has the following properties: to have meaning, to be articulate, universal, common and predicated of several things. In the English translation it is said that the sound ( $\varphi \omega \nu \eta \dot{)})$ is a term ( $\varphi \omega \nu \eta \dot{n})$ loosing a self-referential aspect of speaking about $\varphi \omega \nu \eta \dot{~ i t s e l f ~ a s ~}$ being a $\varphi \omega \nu \eta$. The same effect as of self-descriptive words such as "word," "noun," "term" and so on.

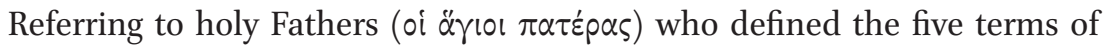
Porphyry ( $\pi \dot{\varepsilon} v \tau \varepsilon \varphi \omega \nu \alpha i)$ as the elements of definition theory, John of Damascus coherently paraphrases Porphyry yet without his own commentaries. ${ }^{37}$ His personal comments are usually placed not in the main content of a chapter but in the beginning or in the end (or in some intermediate parts between chapters). For example he stresses almost each time when he begins to discuss a new term, that this term has a property of being equivocal or homonymous

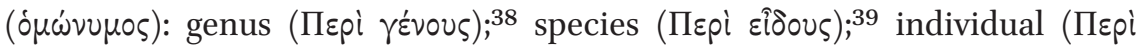

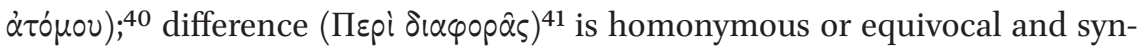

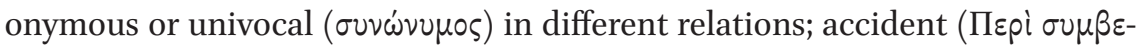

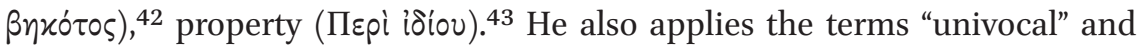
"equivocal" to show how the system of Aristotlian categories works (he stresses that all of categories are equivocal terms). John of Damascus does not invent anything here but he stresses the equivocalness of predicabilia notions illustrating it in his personal way and shifting the view to their meta-linguistic fea-

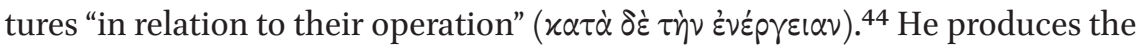
complicated meta-linguistic commentaries: "One should furthermore know that whatever is predicated of something as of a subject, that is, univocally ( $\sigma \nu v \omega v \dot{\mu} \mu \omega \varsigma)$, will also be predicated univocally of what comes under this. In the case of equivocal ( $\delta \mu \omega v \dot{\mu} \mu \omega \varsigma$ ) predication, however, that will by no means be true." 45 Another examples of such a commentary: "that the genus is pre-

\footnotetext{
$36 \quad$ Saint John of Damascus, Writings, tr. Chase, pp. 15-16; PG 94, chap. 5 .

37 Saint John of Damascus, Writings, tr. Chase, p. 18; PG 94, chap. 5.

$38 \quad P G$ 94, chap. 9.

39 Ibid., chap. 10.

40 Ibid., chap. 11.

41 Ibid., chap. 12.

42 Ibid., chap. 13.

43 Ibid., chap. 14.

44 Saint John of Damascus, Writings, tr. Chase, p. 41; $P G$ 94, chap. 12.

45 Saint John of Damascus, Writings, tr. Chase, p. 50; PG 94, chap. 19.
} 


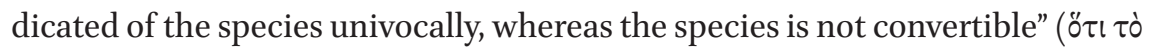

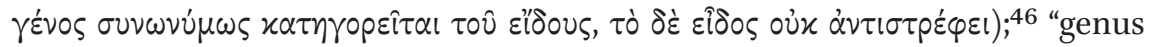

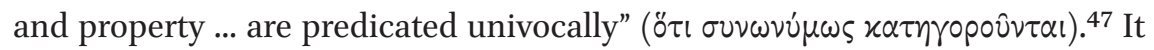
does not refer to self-reference problem directly. But it shows that he intuitively distinguished between levels of language and worked in a style of the famous Russell's paradox solutions (for example the type theory solution):

1. "Difference and quality and property are all the same thing in relation to their subject, but in relation to their operation they are different

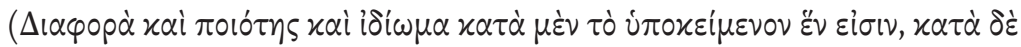

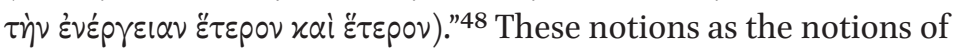
object-language ( $\varkappa \alpha \tau \dot{\alpha} \mu \dot{\varepsilon} \nu \tau \dot{\partial}$ í

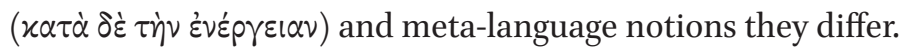

2. "One must know that in the matter of equivocal terms there are three things to be asked: whether the term is equivocal, how many meanings it has, and of which of these it is a question. Now, first of all, it must be explained what an equivocal term is. Terms are equivocal when two or more things have one name, while each one of them has a different meaning, that is to say, takes a different definition. Such is the case with the term genus, for genus is of the number of equivocal terms." ${ }^{49}$

3. "Species is also an equivocal term, since it is used in two different senses." 50

He also named the work The Fount of Knowledge mentioning that it is because of it's status to be the knowledge about the knowledge and his own personal role is just to "set down things which have been said in various places by wise and godly men" saying "nothing of my own" and "first of all, then, it is best to know just what philosophy is." ${ }^{11}$ After this short preamble he gives his famous definition of philosophy which is self-referential - "philosophy is the art of arts and the science of sciences" - that's why it is "the principle of any art" ( $\dot{\alpha} p \times \eta^{\prime}$ $\dot{\varepsilon} \sigma \tau \iota) .{ }^{52}$ This definition the later commentators improperly ascribed to Aristotle [see for example John Italus ${ }^{53}$. Later John Italus would argue that such a

\footnotetext{
46 Saint John of Damascus, Writings, tr. Chase, p. 50; PG 94, chap. 20.

47 Saint John of Damascus, Writings, tr. Chase, p. 51; PG 94, chap. 22.

48 Saint John of Damascus, Writings, tr. Chase, p. 41; PG 94, chap. 12.

49 Saint John of Damascus, Writings, tr. Chase, p. 29; PG 94, chap. 9.

$50 \quad$ Saint John of Damascus, Writings, tr. Chase, p. 31; $P G$ 94, chap. 10.

$51 \quad$ Saint John of Damascus, Writings, tr. Chase, p. 10; $P G$ 94, chap. 2.

$5^{2}$ Saint John of Damascus, Writings, tr. Chase, p. 11; $P G$ 94, chap. 3.

53 Ioannes Italus, Quaestiones quodlibetales, ed. P. Joannou, Buch, 1956, pp. 1-2.
} 
property of philosophy (to be the science of sciences, i.e. to be self-referential activity) makes it to be the only science appropriate to hold such an intellectual enterprise as the cognition of God (the main self-referential, self-existent and self-caused object - $\dot{\alpha} p \times \dot{\eta} \dot{\alpha} p X \hat{\omega} \nu^{54}$ and $\left.\pi \rho \hat{\alpha} \gamma \mu \alpha \alpha \dot{v} \theta \dot{v} \pi \alpha \rho \kappa \tau o v\right) .{ }^{55}$ Only philosophy (due to self-referential nature of its intellectual activity) offers foundations for itself and other sciences and arts. That is also the reason why philosophy is a path to the wisdom and God. Being $\pi \rho \hat{\alpha} \gamma \mu \alpha \alpha \dot{v} \theta \dot{u} \pi \alpha \rho \tau \tau o v$, i.e. "self-subsistent substance" (the English translation sounds more self-referential than its Greek prototype using the one term to formulate the subject and the predicate), ${ }^{56}$ the God structurally corresponds to the way of our philosoph-

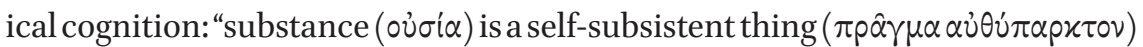
and has no need of another for its existence, and that is all. Thus, substance

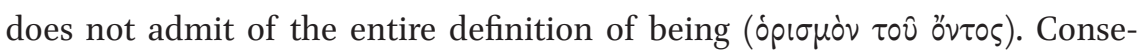
quently, being is not the genus of substance, nor is substance [a species] of being, for the species admits of the definition of its genus in its entirety." ${ }^{57}$

Taking this definition of philosophy into account too, John Italus also develops this line of considering philosophy in the context of self-reference notion (improperly ascribing this definition to Aristotle). In his short treatises Quaes-

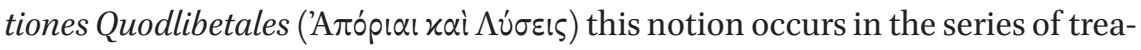
tises..$^{58}$ Let us look just through the several ones:

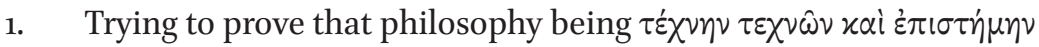

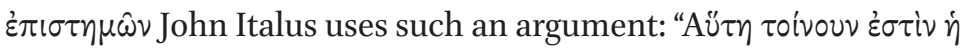

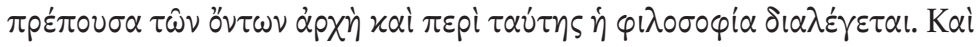

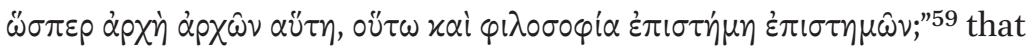
means that the main subject of philosophy is the foundation of being

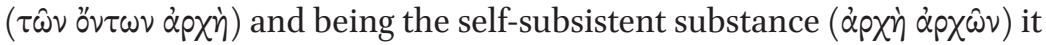
requires self-referential knowledge ( $\dot{\varepsilon} \pi|\sigma \tau \dot{\eta} \mu \eta \dot{\varepsilon} \pi| \sigma \tau \eta \mu \hat{\omega} \nu)$, because the philosophy deals with the foundations of all sciences ( $\pi \varepsilon p i \tau \hat{\omega} v \dot{\alpha} p \chi \hat{\omega} \nu$ $\left.\tau 0^{\prime} \tau \omega \nu \delta 1 \alpha \lambda \alpha \mu \beta \alpha^{\alpha} v \sigma v \sigma \alpha \nu\right) .{ }^{60}$ And the second argument is as follows: all the sciences except philosophy do investigate the subjects as being forms

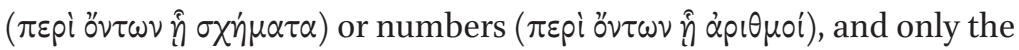

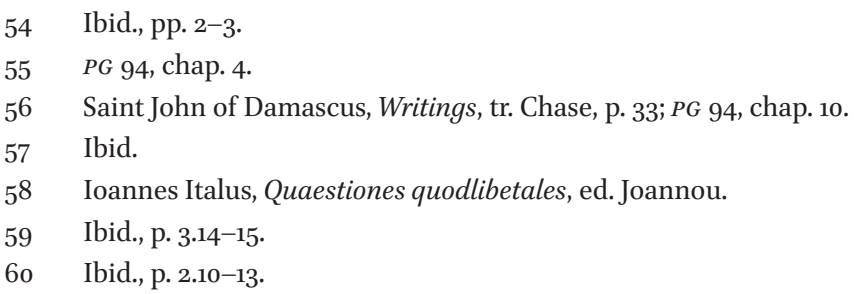




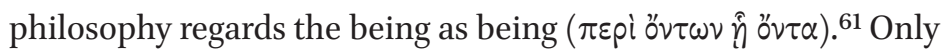
philosophy deals with the self-subsistent substance ( $\dot{\alpha} p \times \dot{\alpha} \dot{\alpha} p x \hat{\omega} v)$ that's why it is to produce the definitions, and first of all the definition of definition (also a self-referential enterprise), i.e. the definition of definition components (genus, species, differentia, etc.). ${ }^{62}$

2. As John of Damascus he also explains that logic is not the part of philosophy, but an instrument, i.e. the knowledge device that makes the knowledge procedure possible, i.e. the fount of knowledge. Of course there may be philosophy without logic, but it is not an easy way to think on the complicated subjects it assumes, so we need logic to make our way to wisdom easier, i.e. to think about the logic matters as the shortest way. So we have two strategies in philosophy and theology: to consider complicated thing (object-language) and than to interpret it in terms of logic (the meta-language that explains our way of thinking on the elements of object-language). ${ }^{63} \mathrm{John}$ Italus also argues that logic may be regarded as the independent and self-sufficient science as geometry or arithmetic because the geometry investigates the subjects as being formable ( $\sigma \eta \mu \varepsilon \hat{0} \nu)$, arithmetic - as being numerable ( $\mu$ ov's), and logic - as being definable (öpos). ${ }^{64}$ Logic according to John of Damascus is an

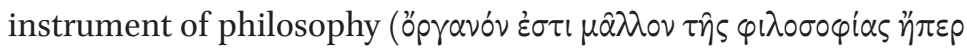

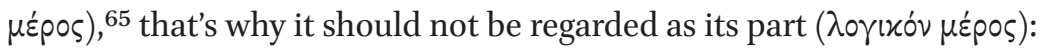
"we are beginning with that division of philosophy which concerns the reason and which is a tool of philosophy rather than one of its divisions, because it is used for every demonstration," ${ }^{\prime 6}$ i.e. logic is a meta-language which describes our thinking. But constructing such a meta-language we have need to discuss it and thus to produce the higher-order language for this purposes. The terms "equivocal," "univocal" and etc. are

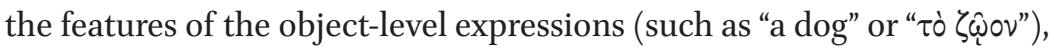
but they also can be applied to characterize the meta-level expressions

$61 \quad$ Ibid., p. 3.17-20.

62 See for example other treatises of Italus in: Ioannes Italus, Quaestiones quodlibetales, ed. Joannou, pp. 7-8, 11-15, 20-21, 23, 25, 27, etc.; see also О. Ю. Гончарко, Д. А. Черноглазов, “Платоновский диалог 'Ксенедем’ Феодора Продрома: псевдоантичные герои и их византийские прототипы” [O. Yu. Goncharko, D. A. Chernoglazov, "Platonic Dialogue of Theodoros Prodromos "Xenedemos": Pseudo-Antique Protagonists, and their Byzantine Prototypes"], Schole, 10 (2016), № 2, pp. 571-582.

63 Ioannes Italus, Quaestiones quodlibetales, ed. Joannou, pp. 17-18.

64 Ibid., p. 3.21-22.

$65 \quad P G 94$, chap. 3

66 Saint John of Damascus, Writings, tr. Chase, p. 13; 
(such as genus, species etc.). John of Damascus and John Italus distinguished these levels, but did not express them evidently. Later Theodoros Prodromos showed that being not distinguished the different language levels could be mixed causing aporias and paradoxes while discussing even the definition theory notions.

3. In the seventh treatise, op. $7,{ }^{67}$ John Italus even defines the phenomenon of self-reference in the neoplatonic terms: the self-subsistent substance is that of producing itself, that's why it is binary or twofold ( $\delta เ \pi \lambda \circ \hat{v} \nu$ ), because the producing ( $\tau \dot{\delta} \pi \alpha \alpha^{\alpha} \gamma \sigma \nu$ ) is the one part of it, and

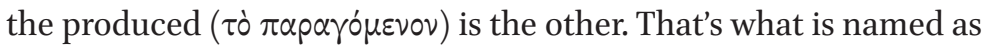
self-subsistent ( $\alpha \dot{v} \theta \dot{\tau} \pi \alpha \rho x \tau \circ v$ ) and self-existent ( $\alpha \dot{v} \theta v \pi \dot{\sigma} \sigma \tau \alpha \tau \sigma \nu$ ) and

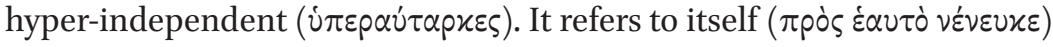
and resembles binary structure as producing and being produced at the

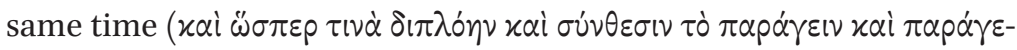

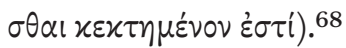

As a conclusion it should be stressed that neither John of Damascus nor John Italus did produce self-reference notion or the meta-level language notion as a concept or term. But they used them implicitly in formulations of their thoughts on logic matters, God and knowledge and even as a method to refute the opponent ideas and approaches. John of Damascus refuting scepticism discarded self-reference in the case of knowledge about the impossibility of knowledge (because of its being paradox) but permitted it in the case of the philosophy definition (because of its being hierarchy of terms).

\subsection{Middle Byzantine Period (12th Cent.)}

And only Theodoros Prodromos (12th cent.) at last is worth of insisting that he at the first time in the history of Byzantine logic sets out the attempt to apply predicabilia notions to define themselves (i.e. as self-descriptive words).

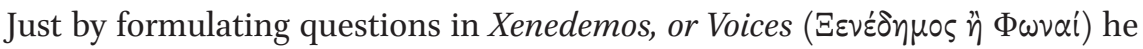
expresses the self-referential character of the definition problem (whether we can define the definition itself?) and applies almost all predicabilia notions within their own definitions. ${ }^{69}$ The dialogue $\Xi \varepsilon v \varepsilon \delta \eta \eta ั \varsigma$ is a little-known philo-

67 Ioannes Italus, Quaestiones quodlibetales, ed. Joannou, pp. 9-10.

68 Ibid., pp. 9.28-10.4.

69 Theodore Prodromus, Xenedemus, sive Voces, ed. Cramer; O. Ю. Гончарко, Д. А. Черноглазов, “Платоновский диалог 'Ксенедем' Феодора Продрома: возрождение платоновского диалога в Византии ХІІ века” [O. Yu. Goncharko, D. A. Chernoglazov, “Theodoros Prodromos 'Xenedemos': Renaissance of Platonic Dialogue in the 12th 
sophical work which is dedicated to the analysis of the five "voices" or predicabilia ( $\varphi \omega v \alpha i$ ) definitions made by Porphyry in Isagoge. The way to discuss the definitions of Porphyry used by Theodoros Prodromos is to make a presentation of logical puzzles or paradoxes just to invite the reader to produce the outlines of their possible solutions. Theodoros Prodromos tries to implement

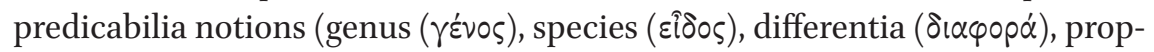
erty (ioiov) and accident ( $\sigma u \mu \beta \varepsilon \beta \eta x o ́ \tau o \varsigma)$ to define themselves. It represents the self-descriptiveness as a basic feature of predicabilia notions in the situations when they are applied to define themselves. Prodromos uses predicabilia as the autological words and terms. In this respect he works strictly as a 2oth century logician or mathematician: the most common recursion application in mathematics is the one where the defining of functions implies defined function as being applied within its own definition. Prodromos attempts to apply the definition rules to define the predicabilia components of definition procedure. It should be mentioned that Porphyry doesn't define (opı $\sigma$ ós $_{\text {) but }}$ describes (i $\pi \circ \gamma p \alpha \varphi \eta$ ) predicabilia, i.e. the predicabilia notions described by Porphyry are understood as axioms (their functions are rather obvious than demonstrated), while Theodoros Prodromos (using the protagonists discussions in the dialogue) tries to assert them as theorems (to define them strictly with applying all the rules of definition). That's why the collocutors (Xenedemos and Theokles) drive to the controversial conclusions each time they try to apply the definition theory itself to define its primitive notions.

The questions asked by protagonists of the dialogue may be reconstructed as follows: whether do exist the genera of genera; what are the species of species; does differentia differ from others kinds of differences; what is the property of property; and whether an accident is accidental itself or not? It is possible to build such questions because predicabilia terms may be regarded as the self-descriptive words: the word "genus" is a genus itself, because we can interpret it as a meta-level function to say that we have at least several genera: the genus of animals, the genus of plants, the genus of minerals, etc. I.e. the word "genus" will be the genus of all this genera. The same situation concerns the other predicabilia: "species" can be interpreted as a kind of species: the

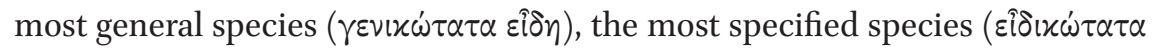
$\varepsilon \hat{\delta} \delta \eta)$, the intermediate ones $(\tau \dot{\alpha} \mu \dot{\varepsilon} \sigma \alpha)$ - they all are the different species of species. And so on. ${ }^{70}$

century Byzantium"], Вестник Русской Христианской Гуманитарной Академии [Review of the Russian Christian Academy for the Humanities], 4.16 (2015), pp. 30-38. 
It should be noted that Theodoros Prodromos might have formulated the Russell's paradox using the five "voices" of Porphyry. So this dialogue can be regarded as the text on the foundations of the logical theory of definition and on the foundation of logic in general. Let us show that the Prodromos "aporias" can be translated into Russell's paradox. The most popular form of the Russell's paradox is formulated in terms of sets or classes. The other form is formulated in terms of properties. Some sets, classes or properties seem to apply to themselves, while others do not. Let us consider the second variation of the Russell's paradox formulation in terms of properties. The property of being a property is itself a property. Does the property "to be the property not appliable to itself" apply to itself? Theodoros Prodromos just asks whether the property is the

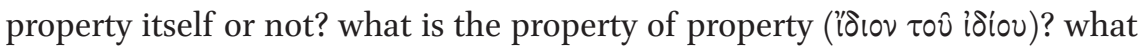
are the differences between different predicabilia? and what are the differenc-

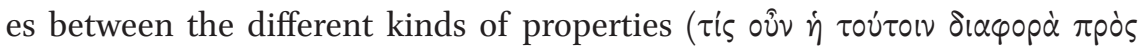

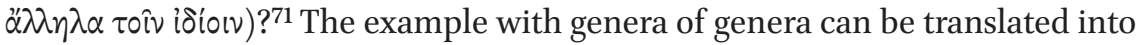
the Russell's paradox in terms of sets or classes: if genus is the genus of all categories, and categories are the genera too, how can the term "genus" be simultaneously the genus and the synonym of the category? Trying to answer these questions the reader of the dialogue is supposed to distinguish meta-language and object-language just to understand properly the properties of properties, genera of genera and species of species, etc. ${ }^{72}$

\section{Conclusions}

To resume with it should be mentioned that after John of Damascus the interest of Byzantine commentators on Porphyry's definition theory shifted from the theoretical approach to the practical implementations. All aporias, sophismata, mistakes or even paradoxes of its applications caused to treat the definition theory not only as an instrument, but as the object of the research interest itself. Such is the situation by the 12th century in Byzantine logic. Theodoros Prodromos adapts and experiments with Porphyry's concepts and drives sometimes to sophistic and sometimes to paradoxical conclusions putting forward the questions which necessarily lead to aporia or mistake.

As far as we know the Byzantines did not produce any way of avoiding Theodoros Prodromos paradoxes (for example in the style of Zermelo-Fraenkel set theory or Russell's type theory). Probably because of the fact that by the time

\footnotetext{
$71 \quad$ Theodore Prodromus, Xenedemus, sive Voces, ed. Cramer, p. 213.14-15.

72 O. Yu. Goncharko, Ya. A. Slinin, D. A. Chernoglazov, "Theodoros Prodromos Logical Works".
} 
of Theodore Metochites and Gregory Palamas the logical tradition developed to the logical scepticism rather than to the epistemological optimism. ${ }^{73}$ May be that was the reason why the Byzantines did not build some solutions as the set theory or the type theory. Nevertheless, we should consider that John of Damascus, John Italus and Theodoros Prodromos took part in the development of the discussion on self-reference too: when John of Damascus gives the definition of philosophy as the science of sciences, he implicitly produces the questions of the following type - whether it is possible to be a science that doubts the scientific nature of science - and at the same time answers "no, because it is a paradox" (it resembles the Grelling-Nelson variation of Russell's paradox); when John Italus explains this definition he creates the hierarchy of scientific levels that presupposes the philosophy as a higher-level degree of reflection and logics as its meta-language, he works in this respect as a 2othcentury semanticist; when Theodoros Prodromos uses predicabilia notions self-descriptively he almost anticipates the Russell's paradox itself.

To resume briefly the Byzantine discussion on self-reference developed by John of Damascus systematization of Greek logic and theological thought, then through John Italus applying it in his dialectical and refutation methods and further to Theodoros Prodromos who was the first Byzantine author to reflect on the foundations of logic using self-reference as a basic feature of its elementary terms and notions.

Western scholars discussed self-reference notion in terms of propositional contradiction and the Liar Paradox, while the Byzantine authors analyzed that of not only on the propositional level, ${ }^{74}$ but also on the level of terms. ${ }^{75}$ (The Byzantine theologians and scholars as usual did not treat self-reference as a fallacy but as a feature of our thinking, ${ }^{76}$ which is generally paraconsistent rather than consistent especially with respect to some logical and theological problems). ${ }^{77}$

73 See in details B. Byden, "To Every Argument is a Counter-Argument: Theodore Metochites' Defence of Scepticism," in: Byzantine Philosophy and its Ancient Sources, ed. K. Ierodiakonou, Oxford, 2002; K. Ierodiakonou, "The Anti-Logical Movement in 14th

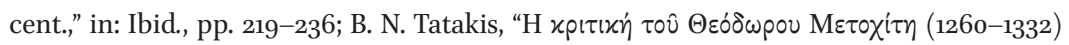

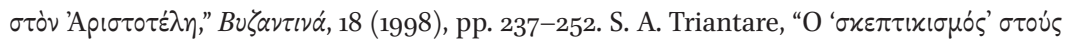

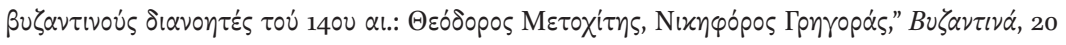
(1999), pp. 43-64.

74 See on Liar Paradox in Byzantium in Gerogiorgskis, "The Byzantine Liar," pp. 313-330.

75 O. Yu. Goncharko, "Thoughts on Self-Reference by John Italus" (forthcoming), and "John of Damascus on Self-Reference in Logics and Theology" (forthcoming).

76 Gerogiorgskis, "The Byzantine Liar," p. 324.

77 B. Lourié, O. Mitrenina, "Semantic of Poetical Tropes: Non-Fregeanity and Paraconsistent Logic," in: Donum Semanticum: Opera Linguistica et Logica in honorem Barbarae Partee a 
Just to outline the future perspectives of the further research of self-reference notion applications in Byzantium it should be mentioned that the Christian Byzantine theology also described name-to-term relationships to solve various theological problems (for example in the context of deification notion, the idolatry discussion or christological argumentation, etc. $)^{78}$

Discipulis Amicisque Rossicis Oblata, ed. P. Arkadiev, I. Kapitonov, Yu. Lander, E. Rakhilina, S. Tatevosov, Moscow, 2015, pp. 180-195. B. Lourié, "Nicephorus Blemmydes on the Holy Trinity and the Paraconsistent Notion of Numbers: A Logical Analysis of a Byzantine Approach to the Filioque," Studia Humana 5 (2016), pp. 40-54.

78 See in details in B. Lourié, "The Philosophy of Dionysius the Areopagite: An Approach to Intensional Semantics," in: Georgian Christian Thought and Its Cultural Context. Memorial Volume for the 125th Anniversary of Shalva Nutsubidze (1888-1969), ed. T. Nutsubidze, C. B. Horn, B. Lourié, with the Collab. of A. Ostrovsky (Texts and Studies in Eastern Christianity, 2), Leiden - Boston, 2014, pp. 81-127; idem, "Philosophy of Dionysius the Areopagite. [Part Two:] Modal Ontology," in: Logic in Orthodox-Christian Thought, ed. A. Schumann, Heusenstamm, 2013, pp. 230-257; idem, "Peter the Iberian and Dionysius the Areopagite: Honigmann-van Esbroeck's Thesis Revisited," Scr, 6 (2010), pp. 143-212; И. Б. Романенко, Образовательные парадигмы в истории античной и средневековой философии [I. В. Romanenko, Educational Paradigms in the History of the Ancient and Medieval Philosophy], St. Petersburg, 2002; Ю. М. Романенко, Бытие и естество: онтология и метафизика как типы философского знания [Yu. M. Romanenko, Being and Nature: Ontology and Metaphysics as the Types of Philosophical Knowledge], St. Petersburg, 2003; Л. Г. Тоноян, Логика и теология Боэиия [L. G. Tonoyan, Logics and Theology of Boethius], St. Petersburg, 2013; Л. Г. Тоноян, Ж. В. Николаева, “Анализ учения Боэция о гипотетических силлогизмах в работах современных итальянских исследователей” [L. G. Tonoyan, Zh. V. Nikolaeva, “An Analysis of the Boethius' Doctrine of Hypothetical Syllogisms in the Works of Modern Italian Researchers"], гХOАH, 10.1 (2016), pp. 294-306. 